\section{Effects of Low-growing Perennial Ornamental Groundcovers on the Growth and Fruiting of 'Seyval blanc' Grapevines}

\author{
N.G. Krohn and D.C. Ferree \\ The Ohio State University, Department of Horticulture and Crop Science, \\ Wooster, OH 44691
}

Additional index words. Vitis, competition, photosynthesis, nutrition, water infiltration

\begin{abstract}
Greenhouse and field-grown 'Seyval blanc' grapevines (Vitis sp.) were grown with low-growing, shallow-rooted, mat-forming, ornamental perennial groundcovers, and the effect of the groundcovers on the vegetative and fruiting growth of the grapevines was evaluated. The groundcovers used in this experiment were 'Kentucky-31' tall fescue (Festuca arundinacea); white mazus (Mazus japoonicus albus); english pennyroyal (Mentha pulegium); dwarf creeping thyme (Thymus serpyllum minus); strawberry clover (Trifolium fragiferum); 'Heavenly Blue' veronica (Veronica prostrata 'Heavenly Blue'); and a companion grass mixture of $75 \%$ perennial ryegrass (Lolium perenne) and $25 \%$ red fescue (Festuca rubra). A control treatment grown without any groundcover was also used in both the greenhouse and field experiments. All of the groundcovers reduced 'Seyval blanc' total shoot length from $22 \%$ to $85 \%$ in the vineyard. Cluster size was reduced in the field from $7 \%$ to $68 \%$ by the groundcovers compared to the herbicide control treatment, and from $9 \%$ to $66 \%$ in the greenhouse experiment, but none of the groundcovers in either the greenhouse or field experiments affected the $\mathrm{pH}$, total acidity, or soluble solids concentrations of the 'Seyval blanc' juice. English pennyroyal was the only groundcover that reduced in the leaf area of the grapevine. Single-leaf photosynthesis of the 'Seyval blanc' grapevines in the field experiment was reduced by all groundcovers except mazus and creeping thyme. Water infiltration rates were 10 to 50 times higher in the groundcovers compared to the bare soil of the herbicide control treatment. Weed growth in the field caused reduction in shoot length similar to the most competitive groundcovers. Weed growth was reduced in the early season by the english pennyroyal and companion grass, and in the late season by all groundcovers. The reduction in growth of the grapevines caused by groundcovers in the greenhouse was a reasonable screen for the affect of groundcovers in the field. The mazus treatment was the only groundcover in our experiments that coupled fast growth with low competitive ability.
\end{abstract}

Vineyards require large amounts of chemical inputs to reach profitable levels of production. Weeds can reduce grapevine growth by up to $40 \%$ (Winkler et al., 1962) and in a newly planted vineyard, the reduction in first-year growth was $81 \%$ (Bordelon and Weller, 1997).

Cover crops are intercropped plants that have been used to control weeds, manage soil nutrients, and reduce soil erosion (Bordelon and Weller, 1997). In the last twenty years, a great deal of research has been conducted to determine the weed-controlling properties of certain cover crops (Hoffman et al., 1995; Klik et al., 1998; Putnam et al., 1983; Teasdale et al., 1990). Many of these studies investigate the properties of plants developed for forage or grain including: rye, vetch, oats, clover, barley, and alfalfa.

Cover crops have also been shown to influ-

Received for publication 1 Dec. 2003. Accepted for publication 1 Jan. 2005. Manuscript no. HCS 03-08. Salaries and research support provided by state and federal funds appropriated to the Ohio Agricultural Research and Development Center, the Ohio State University. We appreciate the support of the George F. Lonz foundation for support of the senior author. ence water infiltration into soils. Slow water infiltration into vineyard soils can be a serious production constraint, leading to lower crop yields, longer or more frequent irrigations, increased runoff, and high evaporative loss (Gulick et al., 1994). Decreased soil water infiltration can be attributed to compaction, mainly through machine use in the vineyards, inwashing of colloids, swelling, and surface sealing (Aljibury and Christensen, 1972). A continuous cover crop of bromegrass (Bromus inesmis) and resident vegetation increased water infiltration rate in soils underneath the grapevine by up to one-third compared to a bare soil herbicide-treated floor (Gulick et al., 1994). As water infiltration rate increased in the presence of cover crops, the expansion of the root system of the cover crop also increased, and compaction of the soil decreased over time (Gulick et al., 1994).

The difficulty in selecting the proper groundcover for a particular vineyard site is in choosing a plant that grows quickly to prevent early season weed growth yet provides little competition with the grapevines. Early season weed growth would likely be abated in the second or third year of the planting, once the groundcover has reached full plot coverage, but early season weed control is very important to growth of young grapevines (Bordelon and Weller, 1997; Ker, 2003), and fast establishment of the groundcover during the first year of planting is important. Slowspreading groundcovers have been related to an increased weed population in comparison to faster growing groundcovers (Clement and DeFrank, 1998).

The effects of competition between plants is less severe in a greenhouse than in a field environment. Hanninen (2002) reported that birch tree leaf area was reduced $30 \%$ by a tall fescue (Festuca arundinacea) companion crop in a greenhouse, but in the field the fescue reduced birch tree leaf area $90 \%$. Any reduction in grapevine growth brought about by a groundcover in the greenhouse would indicate that the same groundcover might reduce vine growth greatly in the vineyard. The objectives of our experiment were to examine the competitiveness of low growing ornamental perennial cover crops to determine their suitability for use in vineyards. A greenhouse study was conducted to evaluate the level of competition of groundcover plants grown with grapevines under non limiting conditions. Afield study was conducted to measure groundcover competition under a natural vineyard environment.

\section{Materials and Methods}

Greenhouse experiment. The seven groundcovers used in this experiment were Festuca arundinacea, 'Kentucky-31' tall fescue; Mazus Japoonicus albus, white mazus; Mentha pulegium, english pennyroyal; Thymus serpyllum minus, dwarf creeping thyme; Trifolium fragiferum, strawberry clover; Veronica prostrata 'Heavenly Blue,' 'Heavenly Blue' veronica; and Companion Grass, a commercial mixture of $75 \%$ perennial ryegrass (Lolium pernne. lurl.) and $25 \%$ red fescue (Festuca rubra L.). Strawberry clover and 'Kentucky-31' tall fescue were purchased as seeds (F\&J Seeds, Mo.), as was the Companion Grass (Peaceful Valley Farm Supply, Grass Valley, Calif.). The veronica, dwarf creeping thyme, mazus, and english pennyroyal were purchased as dormant field-grown plugs (Springbrook Gardens, Mentor, Ohio). Groundcovers were grown with and without grapevines, for a total of 15 treatments with five single vine replications arranged as a randomized complete block design.

The groundcovers that were received as seeds were hand-sown into a 288-cell transplanting flat and placed under mist in the greenhouse. Temperature in the mist room was $30{ }^{\circ} \mathrm{C}$ and water was misted onto the flats for $15 \mathrm{~s}$ every $20 \mathrm{~min}$ until one week after seedling germination. The plants were then moved to a greenhouse bench at $23{ }^{\circ} \mathrm{C}$ for two weeks and watered as needed. At this time, the groundcovers that were received as whole plants were divided into smaller portions and placed into 288-cell transplanting flats under mist as previously described. Since the companion grass treatment was a mixture of two plants, it was started by randomly sowing six seeds into each cell of the 288-cell flats, and was grown in a mixture, rather than as a single plant. 
Own-rooted 'Seyval blanc' grapevines in 8 -L pots were trained to a single stem and grown outside during the summer of the year previous to the experiment and were moved to a $5 \pm 3{ }^{\circ} \mathrm{C}$ dark storage facility in November. Two sets of grapevines were used, one for each year of the study. The grapevines were removed from storage in March 2001 or May 2002. The growth medium was washed from the roots and the roots were cut back to $10 \mathrm{~cm}$ in length. The grapevines were pruned to three nodes on a single shoot. At the times of planting, 30 Mar. 2001 and 15 May 2002, the grapevines were planted into the center of $12-\mathrm{L}$ pots, with six groundcover plugs planted equal distances from each other in a ring around the grapevine. For the treatments with no grapevine, groundcovers were planted in the same pattern. A soil mixture of equal volumes peat, perlite and soil (Wooster silt loam: fine loamy mixed mesic type Fragiudalf) was used as a growth medium. Plants were grown in a greenhouse set at $21 \pm$ $3{ }^{\circ} \mathrm{C}$ day, $15 \pm 3{ }^{\circ} \mathrm{C}$ night temperatures, with natural day length. Plants were weeded and watered as needed, and were fertilized on the first Monday of every month.

When the grapevines had grown enough that the inflorescences could be observed, they were pruned back to the lowest shoot with a viable cluster and trained to a pole inserted in the pot. Laterals and tendrils were removed from the grapevine monthly, and shoot length was measured every other week. When the shoot reached over 15 leaves in height (about $2 \mathrm{~m}$ ), the length of the shoot was measured, and the vines were topped at 15 leaves to facilitate handling and to avoid excessive shading. At destructive harvest, 13 Aug. 2001 (136 d after planting), and 9 Sept. 2002 (147 d after planting), the stem, leaves, and petioles were separated from the grapevines. The area of the leaves was measured using a leaf-area meter (LI-COR, Lincoln, Neb.), after which all portions were bagged, and dried in a $45^{\circ} \mathrm{C}$ forced-draft drying oven. The pots were turned on their side, and the soil ball was removed from the pots. A sharp piece of sheet metal was used to bisect the soil ball, and roots in the upper and lower halves were separated by washing over a wire screen with 4- $\mathrm{mm}^{2}$ holes. The washed roots were bagged and placed in the drying oven.

At harvest, cluster weight, number of berries, and a measurement of good (whole and healthy berries), rot (berries showing signs of rot), and shot (berries small, green, hard, and underdeveloped) berries was determined. The good berries per cluster were weighed and average berry weight calculated. Berries were crushed in a hand mill, and juice was collected. Soluble solids concentration was determined using a refractometer (model 10480 $\mathrm{S} / \mathrm{N}$; Abbe AO Scientific Instruments, Kenne, N.Y.) and $\mathrm{pH}$ was measured on a calibrated digital ionalyzer (AR50, Accumet, Research Dual Channel $\mathrm{pH} / \mathrm{ION} /$ conductivity meter, Fisher Scientific; Pittsburgh, Pa.). Titratable acidity was measured by diluting $5 \mathrm{~mL}$ of juice in $100 \mathrm{~mL}$ of double-distilled water, adding $1 \mathrm{~mL}$ phenolphthalein, and titrating with $1 \mathrm{~N}$ $\mathrm{NaOH}$ to a $\mathrm{pH}$ of 8.2 .
The dry petioles of the vines were ground in a Wiley mill (Arthur H. Thomas Co., Philadelphia, Pa.) to pass through a 40-mesh (0.635-mm) screen. A 1-g subsample of the petioles was sent to the Service Testing and Research laboratories in Wooster, Ohio, for nutrient analysis using an inductively coupled plasma spectrophotometer (Watson and Isaac, 1990).

Visual ratings of groundcover growth (a relative measurement of percentage soil surface covered by the groundcovers) were taken monthly, and following the measurement, groundcover growth exceeding $15 \mathrm{~cm}$ was removed and fresh weights were recorded.

On 26 July 2001, the pots were watered thoroughly, weighed, placed back on the greenhouse bench, and given no more water for $7 \mathrm{~d}$. Photosynthesis measurements $\left(\mathrm{CO}_{2}\right.$ assimilation, stomatal conductance, and transpiration) were taken on the most recently fully expanded leaf of the grapevines every morning starting at 9 AM for $8 \mathrm{~d}$ (CIRAS-1 Portable Photosynthesis System; PPSystems, Hertsfordshire, England). Photosynthesis was measured in the greenhouse under supplemental lighting, to ensure that $>1500 \mu \mathrm{mol} \cdot \mathrm{m}^{-2} \cdot \mathrm{s}^{-1}$ of light reached the measuring chamber. Weights of the pots were also taken for eight days to determine relative water loss among treatments.

Field experiment. Grapevines and groundcovers were planted on 2 June 2001 at Horticulture Unit 2 at the Ohio Agricultural Research and Development Center following an unusually wet spring. The vines used in this study were own-rooted 'Seyval blanc' grapevines, grown outdoors for two previous years in 8$\mathrm{L}$ pots and stored indoors in a $5 \pm 3{ }^{\circ} \mathrm{C}$ dark refrigerated storage during the winters. Vines were removed from the containers and media washed from the roots, and the vines were blocked according to relative size. The vines were planted in east-west rows of a vineyard site that had been fallow for 5 years, with the herbicide strip, one meter wide, maintained with glyphosate (soil type: Wooster silt loam, mixed mesic Fragidaulf). The herbicide strip was roto-tilled to a depth of $10 \mathrm{~cm}$ before planting. Row middles were maintained with mowed sod. Vines were spaced $1 \mathrm{~m}$ in the row with two treatments of three vines each between posts. The treatments were as follows: companion grass; creeping thyme; mazus; english pennyroyal; a mixture treatment consisting of veronica, strawberry clover, mazus, creeping thyme and english pennyroyal; a herbicide treatment with two glyphosate applications (30 Apr. and 29 July 2002) to represent no weed competition; a weeded treatment, which was weeded once (all vegetation removed) on 5 June 2002 to represent low weed competition (late spring weeding); and a weedy treatment, which was never weeded or sprayed with herbicide, to represent high levels of weed competition (no weed control). An application of Poast Plus herbicide (Active ingredient: Sethoxydim 2-[1-(ethoxyimino) butyl]-5-[2-(ethylthio) propyl]-3-hydroxyl-2-cylclohexene-1) was applied to the groundcover plots (except the companion grass and weed growth treatments) on 6 May 2002, to control winter annual grasses that had germinated in the experimental plots. At planting, the vines were about $1.5 \mathrm{~m}$ tall and were attached to the top wire of the trellis with string. As new growth occurred, it was tied to one of the two trellis wires (1.5 and 2 $\mathrm{m}$ high) and left unpruned. Treatments were arranged as a randomized complete block with five replications.

Due to the high temperatures and dry conditions of the two growing seasons of 2001 and 2002 with $\left(26 \mathrm{~d}>90^{\circ} \mathrm{F}\right.$ from 1 June 2001 to 30 Aug. 2001 with $60 \%$ of the normal precipitation for that time period and $31 \mathrm{~d}>90^{\circ} \mathrm{F}$ from 1 June 2002 to 30 Aug. 2002 with $50 \%$ of the average rainfall for that time of year (OARDC historical weather data webpage), watering (30 L of water per plot 10 times each summer) was required both years.

On 3 Oct. $200116.8 \mathrm{~kg} \cdot \mathrm{ha}^{-1}$ of both common lambsquarters (Chenopodium album, CHEAL) and redroot pigweed (Amaranthus retroflexus, AMARE) seeds were hand sown into the plots. This was done to provide a measurable level of weed competition with the groundcovers and grapevines during the following growing season. Growth of the groundcovers, CHEAL, and AMARE, along with any other weeds was rated monthly during 2002. On 5 June 2002, hand-weeding was conducted on the "weeded" treatment, and these weeds were sorted and weighed to estimate the distribution of the weeds species present in the vineyard. Due to the poor growing conditions of Summer 2002 , the weeds never grew $>15 \mathrm{~cm}$ in height and a second weeding was not conducted. Percent cover of broadleaf weed, grass weed, groundcover, and bare soil were estimated three times, on 7 May, 25 June, and 13 Aug. 2002. All ratings were expressed as a percentage of soil coverage by each component.

On 22 Dec. 2002, total shoot length for the center vine of the three in each plot was measured for shoot length and total number of buds per vine counted. Leaf area was measured on 29 Aug. 2002 as previously described. Measurements of grapevine periderm formation were taken visually and expressed as a percentage of total tissue that was brown in color.

The vines used in this experiment had been grown outside in 8-L containers for one full growing season, and developed clusters during the first year of the experiment, and the clusters were thinned to two clusters per vine. In 2001, no measurements were taken of the vines except for a harvest at the end of the growing season on 4 Sept. 2001. The grape clusters in the 2002 growing season were counted as inflorescences on 15 May 2002, and thinned down to a maximum of three clusters per vine. Clusters were harvested on 12 Sept. 2002, and clusters, berries and juice measured as previously discussed.

Photosynthesis, stomatal conductance, and transpiration were measured on the most recently fully expanded leaf of the grapevines on 21 Aug. 2002. Measurements were done at $10 \mathrm{AM}$ on a sunny day with minimal cloud cover, and the light intensity was greater than $1500 \mu \mathrm{mol} \cdot \mathrm{m}^{-2} \cdot \mathrm{s}^{-1}$ for all measurements. Photosynthesis was measured on the middle vine of the three vines in each plot, to minimize 
border effects with equipment and procedures previously described.

On 29 Aug. 2002, a petiole sample of 20 leaves from each plot of three vines were taken from fully expanded leaves. The petioles were dried in a forced-air drying oven at 50 ${ }^{\circ} \mathrm{C}$. Measurements of macro- and micronutrient concentrations in the grapevine petioles were taken using the methods described previously.

To measure differences in water infiltration, PVC tubes ( $20 \mathrm{~cm}$ in width by $35 \mathrm{~cm}$ in depth) that had been sharpened at one end were driven $4 \mathrm{~cm}$ into the soil. One liter of water was added, and the water line was marked on the inside of the PVC tubes. A second liter of water was added, and this line was also marked on the inside of the tubes. The time needed for one liter of water to infiltrate the soil was recorded. Two subsamples per plot were measured, at representative areas to insure the treatment species were present. The measurements were made 3 and 4 Sept. after the groundcovers had maximum coverage of the plot area.

\section{Results}

All groundcovers except creeping thyme and veronica reduced 'Seyval blanc' shoot growth in both 2001 and 2002 (Table 1). Both companion grass and 'Kentucky-31' reduced 'Seyval blanc' shoot growth 35\% relative to the control treatment in both years. English pennyroyal and strawberry clover reduce shoot length $40 \%$ and $36 \%$ both years. The weight of the removed cane at the start of the 2002 growing season was reduced by $50 \%$ in the 'Kentucky-31' and english Pennyroyal treatments compared to the control.

The groundcovers had no effect on the following measurements in the greenhouse experiment: dry weight of grape shoots, petioles, leaves; leaf area, root distribution in the upper and lower halves of the pots; fruit cluster weight, berries per cluster, berry weight; juice $\mathrm{pH}$, soluble solids, titratable acidity; petiole concentrations of $\mathrm{P}, \mathrm{B}, \mathrm{Cu}, \mathrm{Mn}$, and $\mathrm{Mg}$. Only the grapevines in the companion grass treatment exhibited a decrease in petiole $\mathrm{N}$ concentration compared to the control (Table 1). The concentration of $K$ in the grapevine petioles was increased over the control by all groundcovers except creeping thyme and mazus, with the greatest increase occurring in the english pennyroyal and strawberry clover treatments. The english pennyroyal was the only treatment to reduce vine petiole concentrations of Ca relative to the control. The concentration of $\mathrm{Fe}$ in the grapevine petioles was significantly increased relative to the control by the veronica, and was not affected by any other treatment. The english pennyroyal and strawberry clover were the only treatments to significantly reduce vine petiole concentrations of $\mathrm{Al}$ and $\mathrm{Na}$.

About $50 \mathrm{~d}$ after planting, mazus and english pennyroyal reached $100 \%$ pot cover. At this time, pot coverate of the other treatments were as follows: companion grass, $85 \%$; strawberry clover, $84 \%$; 'Kentucky 31 ', 74\%; veronica, $72 \%$; and creeping thyme, $77 \%$.

At the end of the 2001 growing season, mazus and english pennyroyal had the highest dry weight of groundcover shoots removed at the destructive harvest, followed by strawberry clover (Table 2). In 2002, the treatments with the greatest shoot weight were creeping thyme and strawberry clover. Grapevines caused a similar reduction $(21 \%)$ in the shoot dry weight of all clipped groundcovers with no significant interaction in 2001. The interaction in 2002 was significant, with the shoot growth of 'Kentucky-31'being reduced the most by the grapevine and creeping thyme and strawberry clover reduced least.

In both years, the 'Kentucky-31' and companion grass had the greatest amount of total root growth (Table 2). All other groundcovers produced similar amounts of root growth. The 'Kentucky-31' and strawberry clover treatments had the highest percentage of root biomass located in the bottom half of the pots, while mazus and creeping thyme had the lowest, in both 2001 and 2002.

The groundcovers with the largest amount of plant matter trimmed over the course of both growing seasons were strawberry clover and english pennyroyal (Fig. 1). The mazus, veronica and creeping thyme groundcovers had

Table 1. Effects of eight different groundcover treatments on shoot length, total leaf area and petiole nutrient concentrations of container-grown 'Seyval blanc' grapevines in 2001 and 2002. Cane pruning weight was measured after vines were removed from storage in 2002.

\begin{tabular}{|c|c|c|c|c|c|c|c|c|c|c|}
\hline Groundcover & $\begin{array}{c}\text { Shoot } \\
\text { length } \\
\text { (m) } \\
2001\end{array}$ & $\begin{array}{c}\text { Shoot } \\
\text { length } \\
(\mathrm{m}) \\
2002\end{array}$ & $\begin{array}{c}\text { Cane } \\
\text { pruning } \\
\text { wt } \\
(\mathrm{g})\end{array}$ & $\begin{array}{c}\mathrm{N} \\
(\%)\end{array}$ & $\begin{array}{c}\mathrm{K} \\
(\%)\end{array}$ & $\begin{array}{c}\mathrm{Ca} \\
(\%)\end{array}$ & $\begin{array}{c}\mathrm{Fe} \\
(\mathrm{ppm})\end{array}$ & $\begin{array}{c}\text { Al } \\
(\mathrm{ppm})\end{array}$ & $\begin{array}{c}\mathrm{Na} \\
(\mathrm{ppm})\end{array}$ & $\begin{array}{c}\mathrm{Zn} \\
(\mathrm{ppm})\end{array}$ \\
\hline Control & $1.75 \mathrm{a}$ & $1.72 \mathrm{a}^{\mathrm{z}}$ & $39.18 \mathrm{ab}$ & $0.65 \mathrm{a}$ & $3.20 \mathrm{c}$ & $2.28 \mathrm{a}$ & $32.9 \mathrm{abc}$ & $4.32 \mathrm{ab}$ & $1.70 \mathrm{a}$ & $42.2 \mathrm{~b}$ \\
\hline Companion grass & $1.17 \mathrm{c}$ & $1.12 \mathrm{c}$ & $29.02 \mathrm{bc}$ & $0.60 \mathrm{~b}$ & $5.01 \mathrm{~b}$ & $2.26 \mathrm{a}$ & $31.4 \mathrm{bc}$ & $3.94 \mathrm{ab}$ & $1.66 \mathrm{a}$ & $62.1 \mathrm{a}$ \\
\hline Kentucky-31 & $1.12 \mathrm{c}$ & $1.13 \mathrm{c}$ & $20.16 \mathrm{c}$ & $0.61 \mathrm{ab}$ & $5.22 \mathrm{~b}$ & $1.99 \mathrm{ab}$ & $31.7 \mathrm{bc}$ & $4.00 \mathrm{ab}$ & $1.67 \mathrm{a}$ & $51.5 \mathrm{ab}$ \\
\hline Mazus & $1.37 \mathrm{bc}$ & $1.41 \mathrm{~b}$ & $31.29 \mathrm{bc}$ & $0.61 \mathrm{ab}$ & $4.08 \mathrm{c}$ & $2.17 \mathrm{ab}$ & $32.5 \mathrm{abc}$ & $3.42 \mathrm{~b}$ & $1.38 \mathrm{ab}$ & $55.6 \mathrm{ab}$ \\
\hline English pennyroyal & $1.05 \mathrm{c}$ & $1.01 \mathrm{c}$ & $19.55 \mathrm{c}$ & $0.61 \mathrm{ab}$ & $6.42 \mathrm{a}$ & $1.84 \mathrm{~b}$ & $30.2 \mathrm{c}$ & $3.46 \mathrm{~b}$ & $0.99 \mathrm{c}$ & $41.5 \mathrm{~b}$ \\
\hline Strawberry clover & $1.11 \mathrm{c}$ & $1.08 \mathrm{c}$ & $26.78 \mathrm{bc}$ & $0.63 \mathrm{ab}$ & $7.02 \mathrm{a}$ & $2.08 \mathrm{ab}$ & $33.5 \mathrm{ab}$ & $4.78 \mathrm{a}$ & $1.13 \mathrm{bc}$ & $54.5 \mathrm{ab}$ \\
\hline Creeping thyme & $1.87 \mathrm{a}$ & $1.91 \mathrm{a}$ & $45.12 \mathrm{a}$ & $0.66 \mathrm{a}$ & $3.24 \mathrm{c}$ & $2.30 \mathrm{a}$ & $32.4 \mathrm{abc}$ & $4.40 \mathrm{ab}$ & $1.73 \mathrm{a}$ & $47.1 \mathrm{~b}$ \\
\hline Veronica prostratum & $1.55 \mathrm{ab}$ & $1.63 \mathrm{ab}$ & $28.13 \mathrm{bc}$ & $0.61 \mathrm{ab}$ & $5.13 \mathrm{~b}$ & $2.20 \mathrm{a}$ & $35.1 \mathrm{a}$ & $4.10 \mathrm{ab}$ & $1.52 \mathrm{a}$ & $44.8 \mathrm{~b}$ \\
\hline F significance & $* * *$ & $* * *$ & $* * *$ & $*$ & $* * *$ & $*$ & $* *$ & $* *$ & $* * *$ & $* *$ \\
\hline
\end{tabular}

zMean separation conducted using Duncan's multiple range test at $p=0.05$.

${ }^{y}$ Mixture = veronica, strawberry clover, mazus, creeping thyme and english pennyroyal.

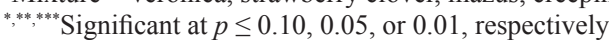

Table 2. Effects of 'Seyval blanc' grapevines on the dry weight distribution $(\mathrm{g})$ of seven groundcover species grown in the same container as the grapevines.

\begin{tabular}{|c|c|c|c|c|c|c|c|c|}
\hline \multirow[b]{3}{*}{ Groundcover } & \multicolumn{4}{|c|}{2001} & \multicolumn{4}{|c|}{2002} \\
\hline & \multirow{2}{*}{$\begin{array}{c}\text { Shoot } \\
\text { wt }\end{array}$} & \multicolumn{2}{|c|}{ Groundcover roots } & \multirow{2}{*}{$\begin{array}{c}\text { Roots in } \\
\text { bottom } \\
(\%)\end{array}$} & \multirow{2}{*}{$\begin{array}{c}\text { Shoot } \\
\text { wt }\end{array}$} & \multicolumn{2}{|c|}{ Groundcover roots } & \multirow{2}{*}{$\begin{array}{c}\text { Roots in } \\
\text { bottom } \\
(\%)\end{array}$} \\
\hline & & Top & Bottom & & & Top & Bottom & \\
\hline Companion grass & $16.4 \mathrm{c}^{\mathrm{z}}$ & $12.3 \mathrm{a}$ & $3.42 \mathrm{~b}$ & $22 \mathrm{~b}$ & $22.2 \mathrm{bc}$ & $24.3 \mathrm{a}$ & $6.0 \mathrm{ab}$ & $20 \mathrm{~b}$ \\
\hline Kentucky-31 & $12.3 \mathrm{c}$ & $8.3 \mathrm{ab}$ & $7.29 \mathrm{a}$ & $47 \mathrm{a}$ & $15.6 \mathrm{~d}$ & $17.4 \mathrm{~b}$ & $8.1 \mathrm{a}$ & $32 \mathrm{a}$ \\
\hline Mazus & $43.4 \mathrm{a}$ & $4.2 \mathrm{bc}$ & $0.37 \mathrm{c}$ & $8 \mathrm{c}$ & $21.6 \mathrm{bc}$ & $8.8 \mathrm{~cd}$ & $0.9 \mathrm{de}$ & $9 \mathrm{c}$ \\
\hline English pennyroyal & $40.1 \mathrm{a}$ & $2.9 \mathrm{c}$ & $0.51 \mathrm{c}$ & $15 \mathrm{~b}$ & $20.8 \mathrm{bcd}$ & $4.5 \mathrm{~d}$ & $1.3 \mathrm{de}$ & $22 \mathrm{~b}$ \\
\hline Strawberry clover & $27.5 \mathrm{~b}$ & $3.0 \mathrm{c}$ & $2.34 \mathrm{bc}$ & $44 a$ & $28.6 a$ & $8.7 \mathrm{~cd}$ & $3.4 \mathrm{~cd}$ & $28 \mathrm{ab}$ \\
\hline Creeping thyme & $15.5 \mathrm{c}$ & $1.6 \mathrm{c}$ & $0.12 \mathrm{c}$ & $7 \mathrm{c}$ & $26.2 \mathrm{ab}$ & $5.8 \mathrm{~cd}$ & $0.5 \mathrm{e}$ & $8 \mathrm{c}$ \\
\hline Veronica prostratium & $16.4 \mathrm{bc}$ & $3.1 \mathrm{c}$ & $0.97 \mathrm{bc}$ & $24 \mathrm{~b}$ & $17.8 \mathrm{~cd}$ & $10.2 \mathrm{c}$ & $4.5 \mathrm{bc}$ & $31 \mathrm{a}$ \\
\hline Without grapevine & $27.3 \mathrm{a}$ & 4.76 & 1.82 & 28 & $23.1 \mathrm{a}$ & 11.5 & 3.5 & 23 \\
\hline With grapevine & $21.7 \mathrm{~b}$ & 5.40 & 2.47 & 31 & $20.6 \mathrm{~b}$ & 10.8 & 3.7 & 26 \\
\hline Groundcover & $* *$ & $* *$ & $* *$ & $* *$ & $* * *$ & $* * *$ & $* * *$ & $* * *$ \\
\hline Grapevine & $*$ & NS & NS & NS & $*$ & NS & NS & NS \\
\hline Groundcover $\times$ grapevine & NS & NS & NS & NS & $* * *$ & NS & NS & NS \\
\hline
\end{tabular}

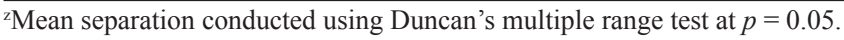

${ }^{y}$ Mixture = veronica, strawberry clover, mazus, creeping thyme and english pennyroyal.

NS,*,**,***** Nonsignificant or significant at $p \leq 0.10,0.05$, or 0.01 , respectively. 


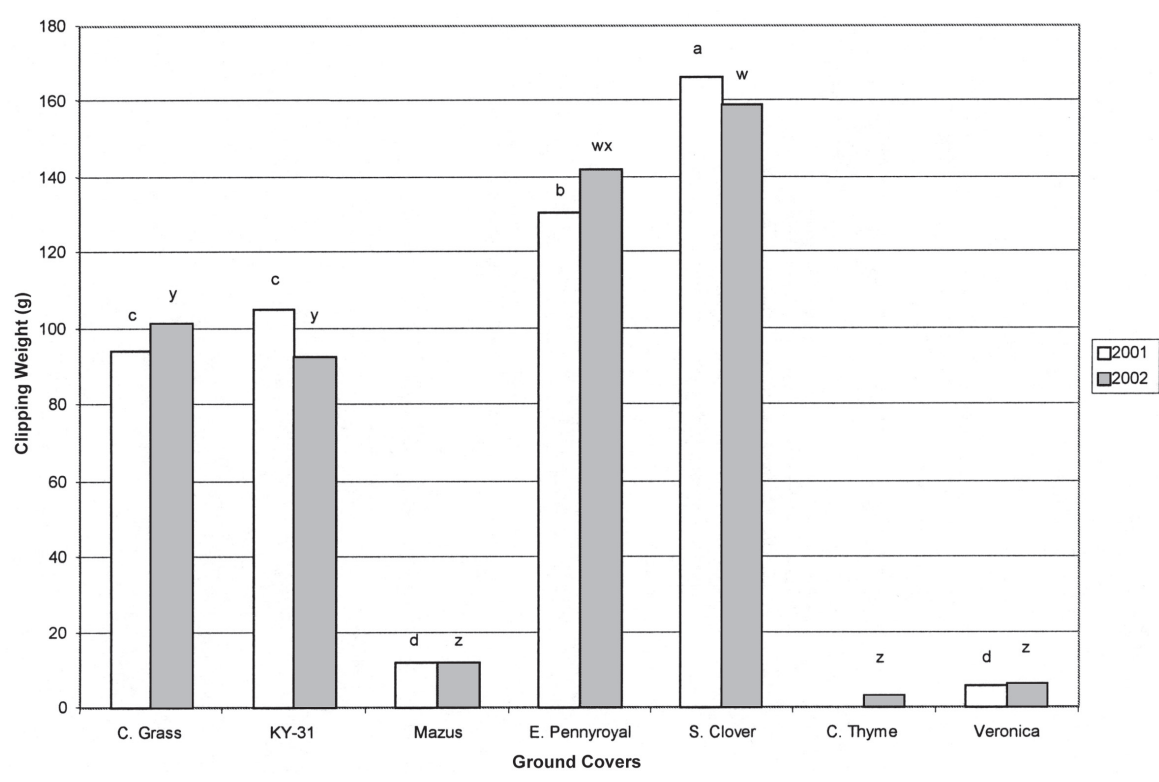

Fig. 1. Total clipping weight removed from groundcover treatments as they grew over $15 \mathrm{~cm}$ in height in 2001 and 2002. Means with the same letter are not significantly different from each other $(2001=\mathrm{a}$, b, c, and d; $2002=\mathrm{w}, \mathrm{x}, \mathrm{y}$, and $\mathrm{z}$ ) via Duncan's multiple range test $(p=0.05)$.

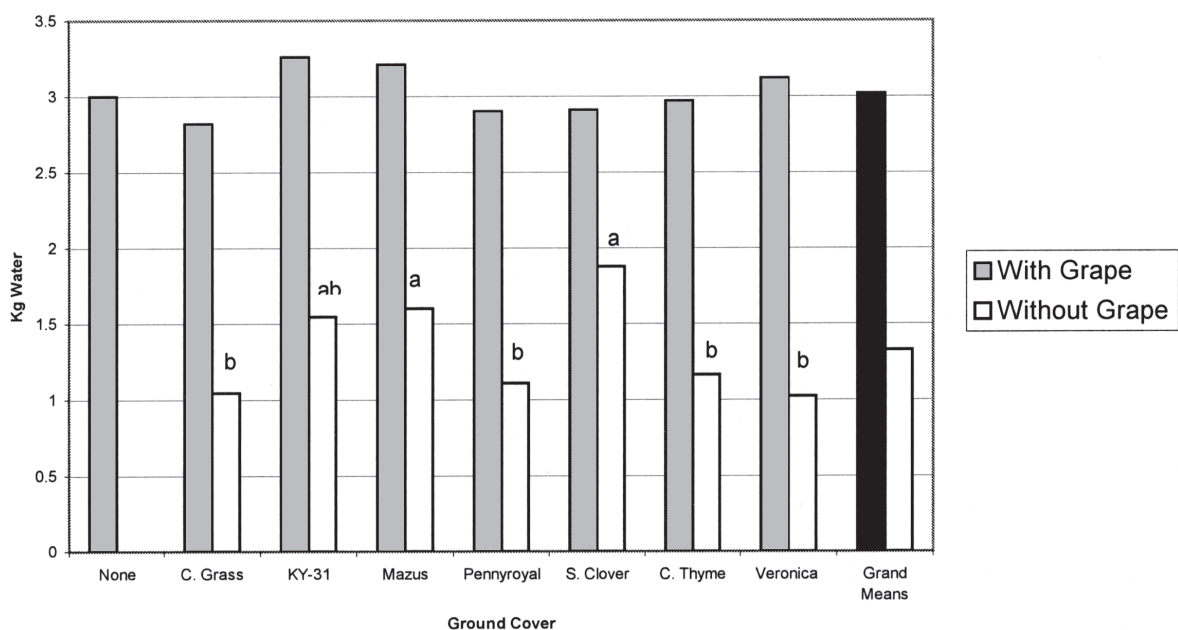

Fig. 2. Weight loss of containers of 'Seyval blanc' and eight groundcovers watered to capacity on 26 July 2001 with no further water applied for $7 \mathrm{~d}$. Means with the same letter are not significantly different from each other via Duncan's multiple range test $(p=0.05)$.

the least amount of clippings removed over both growing seasons, while the companion grass and 'Kentucky-31' were intermediate. The creeping thyme treatment needed no clipping during the 2001 growing season, and very little during the 2002 season. Grapevines caused a $28 \%$ decrease in 2001 and $20 \%$ in 2002 in groundcover clippings.

Treatments with grapevine resulted in a nearly three-fold increase in water lost compared to treatments without a grapevine (Fig. 2). Where a grapevine was present, there were no differences between any of the groundcovers, but where groundcovers were grown alone, differences were apparent. Strawberry clover had the greatest water loss, while the companion grass, english pennyroyal, creeping thyme, and veronica treatments all had lower water loss.

The formation of the periderm of the 'Seyval blanc' grapevines (expressed as a percentage of brown shoot tissue in comparison to green thyme reduced the number of clusters formed $70 \%$ and $54 \%$, respectively compared to the herbicide control (Table 4). The clusters were thinned to a maximum of three clusters per vine after counting, so that each vine would have the same relative cluster sink strength. The average cluster weight from each vine was reduced in this experiment by every treatment except mazus and the late-spring weeding treatment. Cluster weight reduction was $70 \%$ in the english pennyroyal and $60 \%$ in the companion grass treatments compared to the herbicide control. Single berry weight of the 'Seyval blanc' clusters was reduced by the english pennyroyal, companion grass, and no weed control treatments compared to the herbicide control. The number of berries/cluster was decreased in comparison to the herbicide control by english pennyroyal $(63 \%)$, companion grass $(58 \%)$, and creeping thyme $(50 \%)$. None of the groundcovers had any significant effect on $\mathrm{pH}$ or soluble solids levels of the juice from the crushed 'Seyval blanc' berries harvested in 2002 .

The stomatal conductance of the grapevines grown with all groundcovers was lower than the herbicide control (Table 4). The transpiration rates of the grapevine leaves were lowered relative to the herbicide control by all groundcovers except mazus and creeping thyme. Net photosynthesis of 'Seyval blanc' grapevines was not affected by the presence of the mazus or creeping thyme groundcovers, but was lowered by all other groundcovers.

No significant differences were detected in the N or Ca concentrations of the petioles of the grapevines grown with any of the groundcovers (Table 5). The petioles of the grapevines grown in the late-spring weeding $(73 \%)$, no weed control (71\%), english pennyroyal (51\%), and mixture $(15 \%)$ treatments all had lower concentrations of $\mathrm{P}$ than the herbicide control. The petiole concentrations of $\mathrm{K}$ of grapevines grown with companion grass and english pennyroyal were higher than the herbicide control. The Mg concentrations of the 'Seyval blanc' petioles were significantly reduced by the english pennyroyal $(55 \%)$, no weed control $(39 \%)$, mixture $(78 \%)$, and companion grass $(34 \%)$ treatments.

The time required for $1 \mathrm{~L}$ of water to enter the soil of the herbicide control treatment was ten to fifty times greater than the time required for the same amount of water to enter into the soils of any of the groundcover treatments (Fig. 3). The mazus, companion grass, creeping thyme, english pennyroyal, and mixture treatments had the root structure to allow water to enter the soil the fastest, while the late-spring weeding and no weed control treatments required at least four times as long for water to enter the soil as any groundcover treatment.

Early in the spring season, the dominant weeds in all plots were winter annual grasses, and plots had a higher percent of coverage by grass weeds than broadleaf weeds (Table $6)$. The english pennyroyal had the highest percentage of groundcovered early in the growing season, the mixture and companion grass treatments were intermediate, and the 
Table 3. Percentage of periderm development, leaf area, total shoot length, bud number and cluster attributes of field-grown 'Seyval blanc' grapevines as influenced by eight groundcover treatments in 2002.

\begin{tabular}{lcccc}
\hline & $\begin{array}{c}\text { Periderm } \\
\text { developement } \\
(\%)\end{array}$ & $\begin{array}{c}\text { Leaf area } \\
\text { (single leaf) }\end{array}$ & $\begin{array}{c}\text { Total shoot } \\
\text { length }(\mathrm{cm})\end{array}$ & $\begin{array}{c}\text { Buds on } \\
\text { vine (no.) }\end{array}$ \\
Groundcover & $\begin{array}{c}\text { (2) Dec. 2002) } \\
(22 \text { Dec. 2002) }\end{array}$ \\
\hline Herbicide control & $36.7 \mathrm{ab}^{2}$ & $73.6 \mathrm{a}$ & $782 \mathrm{a}$ & $198.0 \mathrm{a}$ \\
Companion grass & $35.3 \mathrm{a}$ & $55.8 \mathrm{ab}$ & $178 \mathrm{~cd}$ & $53.2 \mathrm{e}$ \\
Mazus & $36.6 \mathrm{a}$ & $64.6 \mathrm{ab}$ & $442 \mathrm{~b}$ & $110.2 \mathrm{bc}$ \\
Mixture & $37.6 \mathrm{a}$ & $58.0 \mathrm{ab}$ & $233 \mathrm{bcd}$ & $64.0 \mathrm{cde}$ \\
English pennyroyal & $21.7 \mathrm{~b}$ & $44.5 \mathrm{~b}$ & $80 \mathrm{~d}$ & $30.2 \mathrm{e}$ \\
Creeping thyme & $38.3 \mathrm{a}$ & $73.6 \mathrm{a}$ & $426 \mathrm{~b}$ & $155.0 \mathrm{ab}$ \\
Late-spring weeding & $48.3 \mathrm{a}$ & $66.6 \mathrm{ab}$ & $390 \mathrm{bc}$ & $98.0 \mathrm{~cd}$ \\
No weed control & $41.3 \mathrm{a}$ & $69.5 \mathrm{a}$ & $292 \mathrm{bcd}$ & $86.8 \mathrm{~cd}$ \\
Significance & $* *$ & $*$ & $* * *$ & $* * *$ \\
\hline
\end{tabular}

${ }^{z}$ Mean separation conducted using Duncan's multiple range test at $p=0.05$.

${ }^{\mathrm{y}}$ Mixture $=$ veronica, strawberry clover, mazus, creeping thyme and english pennyroyal.

${ }^{*, * * * * * *}$ Significant at $p \leq 0.10,0.05$, or 0.01 , respectively.

Table 4. Stomatal conductance, transpiration, and net photosynthesis of 'Seyval blanc' grapevines grown with eight different groundcover treatments.

\begin{tabular}{|c|c|c|c|}
\hline Groundcover & $\begin{array}{c}\text { Stomatal } \\
\text { conductance } \\
\left(\mathrm{cm} \cdot \mathrm{s}^{-1}\right)\end{array}$ & $\begin{array}{l}\text { Transpiration } \\
\left(\mu \mathrm{gH}_{2} \mathrm{O} / \mathrm{m}^{2 / \mathrm{s}}\right)\end{array}$ & $\begin{array}{l}\text { Photosynthesis } \\
\left(\mu \mathrm{mol} \mathrm{CO} / \mathrm{m}^{2 / \mathrm{s}}\right)\end{array}$ \\
\hline Herbicide control & $66.4 \mathrm{a}^{\mathrm{z}}$ & $1.53 \mathrm{a}$ & $11.7 \mathrm{a}$ \\
\hline Companion grass & $42.6 \mathrm{~b}$ & $1.32 \mathrm{~b}$ & $9.1 \mathrm{bc}$ \\
\hline Mazus & $44.2 \mathrm{~b}$ & $1.42 \mathrm{ab}$ & $11.2 \mathrm{ab}$ \\
\hline Mixture $^{y}$ & $40.0 \mathrm{~b}$ & $1.24 \mathrm{~b}$ & $8.7 \mathrm{c}$ \\
\hline English pennyroyal & $30.6 \mathrm{~b}$ & $1.21 \mathrm{~b}$ & $8.1 \mathrm{c}$ \\
\hline Creeping thyme & $41.6 \mathrm{~b}$ & $1.45 \mathrm{a}$ & $11.3 \mathrm{a}$ \\
\hline Late-spring weeding & $37.0 \mathrm{~b}$ & $1.35 \mathrm{~b}$ & $8.6 \mathrm{c}$ \\
\hline No weed control & $34.4 \mathrm{~b}$ & $1.38 \mathrm{~b}$ & $7.7 \mathrm{c}$ \\
\hline Significance & $* * *$ & $* * *$ & $* * *$ \\
\hline
\end{tabular}

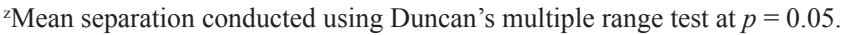

${ }^{y}$ Mixture = veronica, strawberry clover, mazus, creeping thyme and english pennyroyal.

${ }^{* * * *}$ Significant at $p \leq 0.01$.

creeping thyme had the lowest percentage of groundcovered on 7 May 2002. Among all groundcovers, creeping thyme and mazus had the highest percentage of bare soil (not covered by any vegetation), while the companion grass, mixture, and english pennyroyal all had significantly lower percentages of bare soil.

When the weeds were removed from the late spring weeded treatment on 5 June 2002, they were weighed to evaluate the weed population in the soil. The dominant weed species in all five replications of the experiment were $68 \%$ ryegrass (Lolium species) and $25 \%$ quackgrass [Elytrigia repens (L.) Nevski] of the total weed biomass. The other weeds found in the soils of this experiment were annual bluegrass ( $\mathrm{Poa}$ annua), canada bluegrass (Poa compressa), slender rush (Juneus tennis Willd.), pennsylvania smartweed (Polygonum pennsylvanicum L.), common lambsquarters (Chenopodium subsequent increase in the bare soil percent coverage. The companion grass and mazus groundcovers increased in percent plot coverage $9 \%$ and $12 \%$ respectively from 7 May to 25 June, but the mixture and english pennyroyal groundcovers exhibited only a slight increase in groundcover total plot coverage. The creeping thyme coverage did not increase from 7 May to 25 June, but bare soil coverage declined, due to the increasing presence of the common lambsquarters.

The growth ratings taken on $13 \mathrm{Aug}$. begin to show the emergence of the redroot pigweed plants, which, coupled with common lambsquarter, resulted in high levels of broadleaf weed coverage in mazus and creeping thyme (Table 6). Nearly $60 \%$ of the weeds in the late-spring weeding plots as of 13 Aug. 2002 were comprised of either redroot pigweed or common lambsquarters. The groundcovers had all exceeded $75 \%$ plot coverage by the time of this measurement, except for the creeping thyme, which had only covered $40 \%$ of the plot area. The creeping thyme also had the highest levels of bare soil compared to the other groundcovers.

On 13 Aug. 2002, the ratings of the common lambsquarters and redroot pigweed in all plots were recorded (Fig. 4). The groundcover treatment with the highest percentage of groundcovered by common lambsquarters was the late-spring weeding treatment, while the companion grass, mixture, and english pennyroyal had the lowest percentage of plot coverage by common lambsquarters. The mazus and creeping thyme treatments had intermediate levels of common lambsquarters plot coverage. Emergence of redroot pigweed was the highest in the no weed control and late-spring weeding plots, and was significantly lower in all groundcover plots. There was no difference among the groundcover plots in percentage covered by redroot pigweed plants.

\section{Discussion} rows, and the broadleaf percent plot coverage increased (Table 5). The 25 June ratings was taken after the spray of the grass-selective herbicide Poast Plus was used on all plots (except the companion grass, late-spring weeding, and no weed control treatments), and the reduction in grass weeds from 7 May to 25 June reflects this. The removal of all vegetation from the late-spring weeding plot resulted in very low numbers for broadleaf and grass weeds in the late-spring weeding treatment, and a

album L.), canada thistle (Eirsium arvense dandelion (Taraxacum officinals Weber in iggers), mousear chickweed (Cerasti were too small to differentiate into species.

By 25 June, the common lambsquarters seeds that had been planted in 2001 were

\section{Discussion}

The most competitive groundcovers in our experiments reduced 'Seyval blanc' shoot growth in both the greenhouse and field experiments. In the field experiment, all groundcover treatments reduced 'Seyval blanc' total shoot length compared to the bare soil control, but in the greenhouse, the creeping thyme, mazus, and veronica treatments did not reduce 'Seyval blanc' shoot length, most likely as a

Table 5. Effects of eight groundcovers on cluster attributes and petiole macronutrient concentrations of field-grown 'Seyval blanc' grapevines.

\begin{tabular}{|c|c|c|c|c|c|c|c|c|c|}
\hline Groundcover & $\begin{array}{l}\text { Clusters (no.) } \\
\text { (25 Apr. 2002) }\end{array}$ & $\begin{array}{l}\text { Cluster } \\
\text { wt (g) }\end{array}$ & $\begin{array}{c}\text { Single } \\
\text { berry } \\
\text { wt }(g)\end{array}$ & $\begin{array}{l}\text { Berries/ } \\
\text { cluster }\end{array}$ & $\begin{array}{c}\mathrm{N} \\
(\%)\end{array}$ & $\begin{array}{c}\mathrm{P} \\
\left(\mu \mathrm{g} \cdot \mathrm{g}^{-1}\right)\end{array}$ & $\begin{array}{c}\mathrm{K} \\
\left(\mu \mathrm{g} \cdot \mathrm{g}^{-1}\right)\end{array}$ & $\begin{array}{c}\mathrm{Ca} \\
\left(\mu \mathrm{g} \cdot \mathrm{g}^{-1}\right)\end{array}$ & $\begin{array}{c}\mathrm{Mg} \\
\left(\mu \mathrm{g} \cdot \mathrm{g}^{-1}\right)\end{array}$ \\
\hline Herbicide & $13.6 \mathrm{a}^{\mathrm{z}}$ & $76.8 \mathrm{a}$ & $1.35 \mathrm{ab}$ & $165 \mathrm{a}$ & 0.72 & $0.27 \mathrm{ab}$ & $1.71 \mathrm{~cd}$ & 1.3 & $0.73 \mathrm{a}$ \\
\hline Companion grass & $8.6 \mathrm{abc}$ & $28.2 \mathrm{~cd}$ & $1.11 \mathrm{de}$ & $72 \mathrm{c}$ & 0.53 & $0.18 \mathrm{bc}$ & $2.87 \mathrm{a}$ & 1.7 & $0.49 \mathrm{bcd}$ \\
\hline Mazus & $11.5 \mathrm{ab}$ & $71.1 \mathrm{ab}$ & $1.37 \mathrm{a}$ & $151 \mathrm{ab}$ & 0.64 & $0.24 \mathrm{ab}$ & $1.76 \mathrm{bcd}$ & 1.43 & $0.66 \mathrm{abc}$ \\
\hline Mixture $^{y}$ & $9.6 \mathrm{abc}$ & $43.7 \mathrm{bcd}$ & $1.22 \mathrm{bcd}$ & $101 \mathrm{abc}$ & 0.66 & $0.12 \mathrm{~cd}$ & $2.25 \mathrm{abc}$ & 1.33 & $0.46 \mathrm{bcd}$ \\
\hline English pennyroyal & $4.1 \mathrm{c}$ & $22.6 \mathrm{~d}$ & $1.05 \mathrm{e}$ & $62 \mathrm{c}$ & 0.67 & $0.12 \mathrm{~cd}$ & $2.52 \mathrm{ab}$ & 1.37 & $0.32 \mathrm{~d}$ \\
\hline Creeping thyme & $6.3 \mathrm{bc}$ & $41.1 \mathrm{~cd}$ & $1.28 \mathrm{abc}$ & 85 bc & 0.85 & $0.30 \mathrm{a}$ & $1.63 \mathrm{~cd}$ & 1.33 & $0.67 \mathrm{abc}$ \\
\hline Late-spring weeding & $8.6 \mathrm{abc}$ & $57.6 \mathrm{abc}$ & $1.30 \mathrm{abc}$ & $128 \mathrm{abc}$ & 0.65 & $0.07 \mathrm{~d}$ & $1.33 \mathrm{~d}$ & 1.39 & $0.70 \mathrm{ab}$ \\
\hline No weed control & $9.0 \mathrm{abc}$ & $45.6 \mathrm{bcd}$ & 1.18 cde & $110 \mathrm{abc}$ & 0.64 & $0.08 \mathrm{~d}$ & $2.23 \mathrm{abc}$ & 1.23 & $0.45 \mathrm{~cd}$ \\
\hline Groundcover & $* * *$ & $* * *$ & $* * *$ & $* *$ & NS & $* * *$ & $* * *$ & NS & $* * *$ \\
\hline
\end{tabular}

${ }^{\mathrm{z}}$ Mean separation conducted using Duncan's multiple range test at $p=0.05$.

y Mixture = veronica, strawberry clover, mazus, creeping thyme and english pennyroyal.

$\mathrm{NS}, * * * * * * *$ Nonsignificant or significant at $p \leq 0.05$ or 0.01 , respectively. 


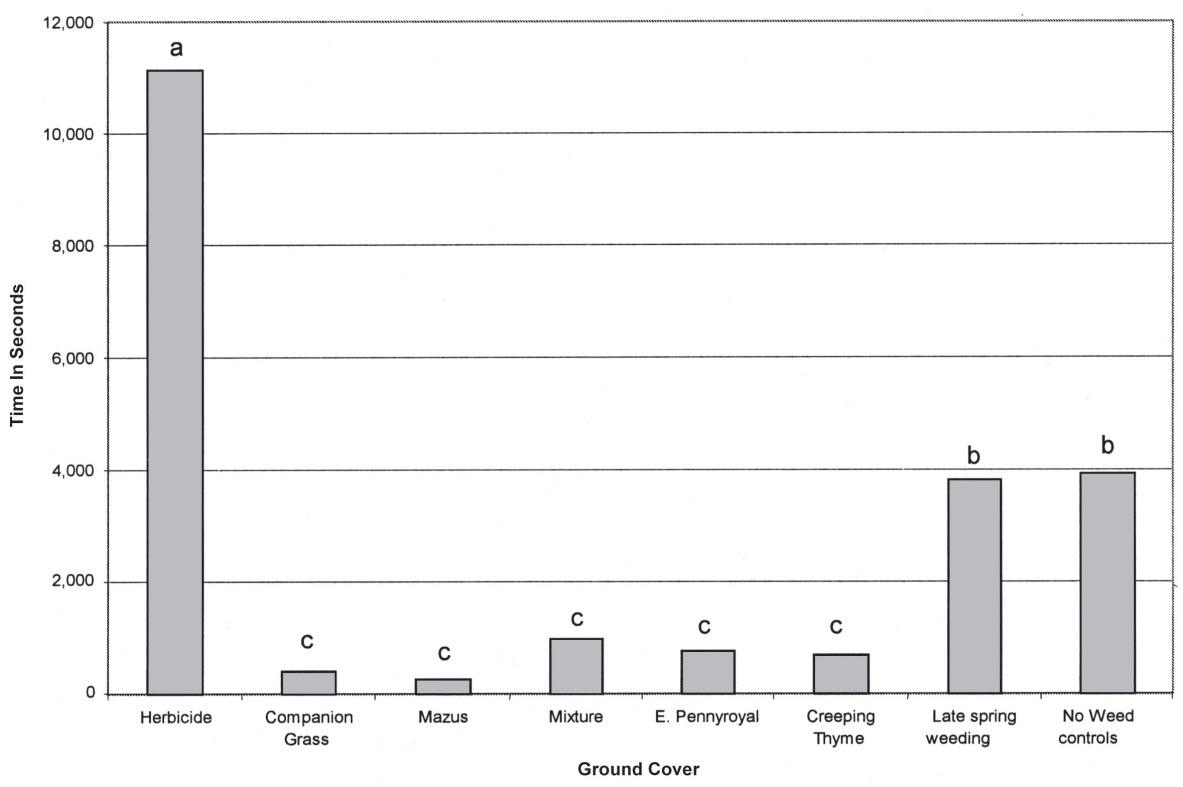

Fig. 3. Seconds required for one liter of water to enter vineyard soil (soil type: Wooster silt loam, mixed mesic Fragidaulf) from a cylinder $20 \mathrm{~cm}$ in width and $30 \mathrm{~cm}$ in depth in eight groundcover regimes. All means with the same letter designation are not significantly different from each other via Duncan's multiple range test $(p=0.05)$.

result of adequate moisture and non-stressful temperatures. In the experiment conducted by Hanninen (2002), the cover crops used were seven clover species and one Festuca (fescue) species and similar results were found: birch tree shoot growth was reduced nearly $20 \%$ and leaf area by $30 \%$ with all cover crops in the greenhouse (Hanninen, 2002). In the field, Hanninen found that the fescue treatment reduced birch tree shoot growth 50\% and leaf area $90 \%$. Skroch and Shribbs (1986) reported a similar decrease in leaf size and leaf area in apple trees grown in an orchard due to competition with fescue grasses. In our experiments, both companion grass and english pennyroyal were more competitive with the 'Seyval blanc' grapevines in the field than in the greenhouse, reducing 'Seyval blanc' leaf area by $41 \%$ and $24 \%$ respectively in the field, and by $22 \%$ and $18 \%$ respectively in the greenhouse. The english pennyroyal and companion grass treatments reduced 'Seyval blanc' shoot growth in the field by $91 \%$ and $77 \%$, and by $40 \%$ and $33 \%$ in the greenhouse. Although differences in degree of competition existed between field and greenhouse, the greenhouse results were reasonable in predicting the results in the field and could provide a means of screening potential cover crops for vineyards.

In our greenhouse experiments, the concentrations of $\mathrm{N}$ located in the grapevine petioles for all groundcover treatments were below deficient levels (Cahoon, 1980). Both $\mathrm{N}$ and $P$ have been shown to decline in concentration in the leaves and petioles of the grapevine as the growing season progresses, until leaf senescence (Boselli et al., 1998). The petioles in the greenhouse experiment were collected at the time of cluster harvest, when petiole $\mathrm{N}$ concentrations are at their lowest, and this may explain the low concentrations of grapevine ciency were observed in the grapevines. The levels of Pwere not deficient in our greenhouse experiment in any groundcover treatment, nor were the levels of any other macro- or micronutrients below deficiency concentraconcentration of vine petiole $\mathrm{K}$ in treatments with the english pennyroyal, strawberry clover, companion grass, 'Kentucky-31', and veronica groundcovers is similar to the increase seen in petiole $\mathrm{N}$, as no obvious symptoms of $\mathrm{N}$ defitions (Cahoon, 1980). The increase in the the field experiment. The petioles of the english pennyroyal and companion grass treatment (two treatments which showed an increase in grapevine petiole concentrations of $\mathrm{K}$ ) in the greenhouse experiment were smaller in weight than the bare soil control treatment (1.12 and $1.26 \mathrm{~g}$, compared to $1.56 \mathrm{~g}$ in the control treatment), and it is likely that the measured increase in vine petiole concentration of $\mathrm{K}$ is a reflection of equivalent $\mathrm{K}$ uptake concentrated into smaller petioles. The concentration of $\mathrm{K}$ in the petioles of the grapevines grown in the field experiment was also highest in the english pennyroyal and companion grass treatment. Similar findings were observed in experiments on apple trees grown with competitive understory plants (Rivera, 2002), tree concentrations of $\mathrm{P}$ and $\mathrm{K}$ were higher in the most competitive treatments, but tree size in those same treatments was greatly decreased over the control treatments.

Groundcover shoot biomass production over the growing season (measured in the fresh weights of groundcover shoot clippings) has a strong negative correlation with the reduction in grapevine shoot growth $(r=-0.86$ in 2001 , and $r=-0.89$ in 2002), suggesting that an increase in above ground shoot growth by a groundcover will result in a decrease in grapevine shoot growth. Bordelon and Weller(1997) showed that rye, wheat (Triticum aestivum $\mathrm{L}$. 'Cardinal'), oats (Avena sativa L. 'Ogle'), and hairy vetch (Vicia villosa Roth) all reduced grapevine shoot growth $54 \%$ to $77 \%$ compared to a bare soil control treatment, while weeds that were allowed to grow freely in the vine row reduced vine growth by $81 \%$ (Bordelon and Weller, 1997).

The measurements of photosynthesis on our greenhouse grapevines were taken at veraison, a phenoperiod shown to have the highest levels of photosynthesis on 'Seyval blanc' grapevines when the most recent fully expanded leaf is used (Edson et al., 1995). Grapevine photosynthesis during veraison has been shown to be very sensitive to levels of water stress. In 'Concord' grapevines, water deficit stress reduced net photosynthesis $24 \%$ to $41 \%$ before veraison, and $31 \%$ to $66 \%$ during veraison (Smithyman et al., 2001). In our greenhouse experiments, the competition from the groundcovers, coupled with the water stress caused by not watering the grapevines for eight days, had a similar effect during both years of

Table 6. Growth ratings of broadleaf weeds (BW), grass weeds (GW), and groundcover (GC), taken on three dates in 2002, expressed as a percentage of plot coverage for each of the four categories below.

\begin{tabular}{|c|c|c|c|c|c|c|c|c|c|c|c|c|}
\hline \multirow[b]{2}{*}{ Groundcover } & \multicolumn{4}{|c|}{7 May 2002} & \multicolumn{4}{|c|}{25 June 2002} & \multicolumn{4}{|c|}{13 Aug. 2002} \\
\hline & $\mathrm{BW}$ & GW & $\mathrm{GC}$ & Bare soil & BW & GW & GC & Bare soil & BW & GW & $\mathrm{GC}$ & Bare soil \\
\hline Herbicide control & $0 \mathrm{a}^{\mathrm{z}}$ & $0 \mathrm{a}$ & $0 \mathrm{a}$ & $100 \mathrm{~d}$ & $0 \mathrm{a}$ & $0 \mathrm{a}$ & $0 \mathrm{a}$ & $100 \mathrm{~d}$ & $0 \mathrm{a}$ & $0 \mathrm{a}$ & $0 \mathrm{a}$ & $100 \mathrm{~d}$ \\
\hline Companion grass & $5 \mathrm{~b}$ & $10 \mathrm{ab}$ & $73 \mathrm{c}$ & $10 \mathrm{a}$ & $4 \mathrm{a}$ & $7 \mathrm{ab}$ & $82 \mathrm{c}$ & $7 \mathrm{a}$ & $7 \mathrm{a}$ & $5 \mathrm{a}$ & $85 \mathrm{c}$ & $3 a$ \\
\hline Mazus & $6 \mathrm{~b}$ & $18 \mathrm{~b}$ & $48 \mathrm{c}$ & $28 \mathrm{bc}$ & $14 \mathrm{ab}$ & $3 \mathrm{a}$ & $60 \mathrm{bc}$ & $22 \mathrm{~b}$ & $10 \mathrm{a}$ & $1 \mathrm{a}$ & $75 \mathrm{c}$ & $14 \mathrm{~b}$ \\
\hline Mixture $^{y}$ & $2 \mathrm{a}$ & $10 \mathrm{ab}$ & $80 \mathrm{~cd}$ & $8 \mathrm{a}$ & $9 \mathrm{a}$ & $0 \mathrm{a}$ & $81 \mathrm{c}$ & $10 \mathrm{a}$ & $7 \mathrm{a}$ & $0 \mathrm{a}$ & $85 \mathrm{c}$ & $8 \mathrm{a}$ \\
\hline English pennyroyal & $1 \mathrm{a}$ & $6 \mathrm{a}$ & $88 \mathrm{~d}$ & $5 \mathrm{a}$ & $6 a$ & $1 \mathrm{a}$ & $90 \mathrm{~d}$ & $2 \mathrm{a}$ & $7 \mathrm{a}$ & $1 \mathrm{a}$ & $90 \mathrm{c}$ & $2 \mathrm{a}$ \\
\hline Creeping thyme & $9 \mathrm{bc}$ & $25 \mathrm{bc}$ & $25 \mathrm{~b}$ & $41 \mathrm{c}$ & $22 \mathrm{~b}$ & $5 \mathrm{a}$ & $40 \mathrm{~b}$ & $33 \mathrm{~b}$ & $22 \mathrm{~b}$ & $3 \mathrm{a}$ & $45 \mathrm{~b}$ & $30 \mathrm{bc}$ \\
\hline Late-spring weeding & $17 \mathrm{c}$ & $52 \mathrm{c}$ & $0 \mathrm{a}$ & $31 \mathrm{bc}$ & $23 \mathrm{~b}$ & $13 \mathrm{ab}$ & $0 \mathrm{a}$ & $64 \mathrm{c}$ & $58 \mathrm{c}$ & $25 \mathrm{~b}$ & $0 \mathrm{a}$ & $15 \mathrm{~b}$ \\
\hline No weed control & $22 \mathrm{c}$ & $59 \mathrm{c}$ & $0 \mathrm{a}$ & $19 \mathrm{ab}$ & $33 \mathrm{~b}$ & $52 \mathrm{c}$ & $0 \mathrm{a}$ & $15 \mathrm{a}$ & $42 \mathrm{bc}$ & $46 \mathrm{c}$ & $0 \mathrm{a}$ & $12 \mathrm{~b}$ \\
\hline Significance & $*$ & $* *$ & $* * *$ & $* * *$ & $* *$ & $* * *$ & $* * *$ & $* * *$ & $* *$ & $* * *$ & $* * *$ & $* * *$ \\
\hline
\end{tabular}

${ }^{2}$ Mean separation conducted using Duncan's multiple range test at $p=0.05$.

${ }^{\mathrm{y}}$ Mixture $=$ veronica, strawberry clover, mazus, creeping thyme and english pennyroyal.

${ }^{*, * * * * * *}$ Significant at $p \leq 0.10,0.05$, or 0.01 , respectively. 


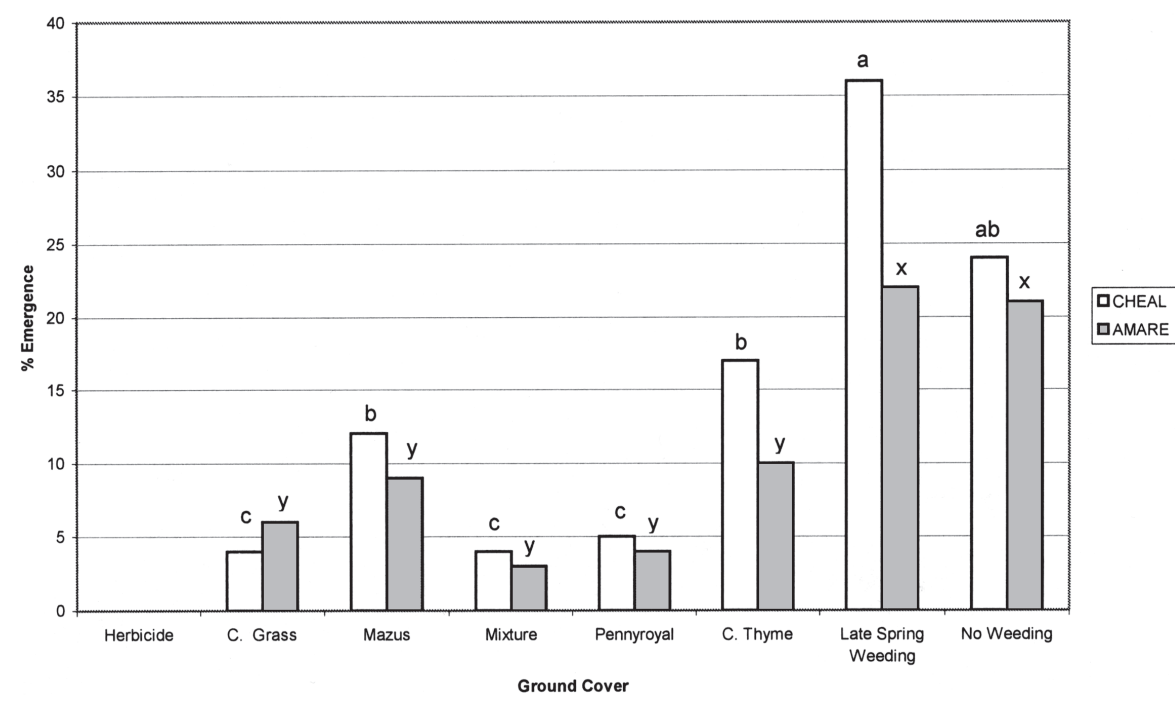

Fig. 4. Average percent emergence of CHEAL (common lambsquarters) and AMARE (redroot pigweed) in the groundcover plots grown with three 'Seyval blanc' grapevines. Weeds were hand sown on 3 Oct. 2001 at $16.8 \mathrm{~kg} \cdot \mathrm{ha}^{-1}$. Ratings were done visually on 14 Aug. 2002. Means with the same letter designation are not significantly different from each other $(\mathrm{CHEAL}=\mathrm{a}, \mathrm{b}$, and $\mathrm{c}$; AMARE $=\mathrm{x}, \mathrm{y}$, and z) via Duncan's multiple range test $(p=0.05)$.

the experiment on 'Seyval blanc' single-leaf photosynthesis. It is possible that 'Kentucky31'was allelopathic (Smith et al., 2001) which would explain the reduction in 'Seyval blanc' net photosynthesis, and leaf area in both years. Allelochemicals have been shown to reduce net photosynthesis of various plants (Hejl et al., 1993; Kohli et al., 1998), but little research has been conducted on the effects of water stress and competition from other plants on grapevine single-leaf photosynthesis.

The grapevines used for both the greenhouse and field portions of this study were grown outside in the year 2000, in an area with ample sunlight, and were watered and fertilized on a regular basis. Since the flower initiation of a grapevine is conducted during the middle of the growing season the year before the clusters develop on the vines (Winkler et al., 1962), it is logical that no differences would be seen in the number of clusters formed on the grapevines in the field in 2001. The reduction in second year cluster formation in the field (2002) indicates that the english pennyroyal competed with the grapevines at the time of flower initiation in 2001. Grapevine concentrations of $\mathrm{P}$ have been shown to affect the formation of cluster primordia, effectively reducing the number of clusters on a given grapevine (Skinner et al., 1988). Grapevine nutrient concentrations were not measured in the field in the 2001 growing season, but in the 2002 season the english pennyroyal decreased grapevine petiole P concentration to deficient levels (Cahoon, 1980), which may account for the reduction in the number of clusters seen at the start of the 2002 growing season.

It is likely that many of the competitive effects exhibited on the grapevines by the groundcovers in this study were a result of the groundcovers placing the grapevines into various degrees of water stress. The grapevines in our study exhibited decreases in stomatal conductance and transpiration (Table 4), and for use in a vineyard. The mazus treatment emerged as a groundcover that might have practical application for use in the vine rows of a vineyard. The mazus groundcover did not reduce 'Seyval blanc' cluster size or juice $\mathrm{pH}$, total acidity, and soluble solids concentrations, and mazus did not reduce the net photosynthesis of the 'Seyval blanc' grapevines. Mazus established itself at a rate equal to the english pennyroyal and companion grass treatments, but produced $70 \%$ less above ground-growth than either of those two groundcovers. The mazus groundcover is likely acting as a relatively inert form of living mulch. Living mulches have been shown to be more effective than dead or dessicated mulches at suppressing weed seed germination (Teasdale and Mohler, 1993), and non-competitive treatments have been shown to retain the same relative amount of additional soil moisture, while using less water than a competitive treatment (Teasdale and Daughtry, 1993). Mazus also reduced 'Seyval blanc' shoot growth, but to a much lesser degree than any of the competitive groundcovers discussed above. Many vineyards are operated on sites that give excess vine vigor, and a reduction in shoot growth could be viewed as a positive by many growers, especially given the fact that the cluster and juice attributes were not affected by the mazus groundcover in the field experiment. The herbicide treatment had the most favorable attributes for 'Seyval blanc' grape production in nearly all measurements of our experiment, and it is clear why herbicides have been used in viticulture for such a long time. However, given the fact that most vineyards operate on a cycle that can be many decades long, there will always be a need for sustainable horticultural practices in grape production, and the many benefits of using groundcovers can outweigh the expensive monetary costs of the initial plantings.

\section{Literature Cited}

provided by a groundcover or cover crop have shown increased rates of water infiltration in any treatment where resident vegetation was present (Gulick et al., 1994; Folorunso et al., 1992; Aljibury and Christensen, 1972). The decomposition and turnover of root systems in the soil leaves behind channels through which water can travel (Locke and Bryson, 1997). The homogeneity of the root penetration into the soil in the groundcover treatments can explain the improvement in water infiltration rates over the weedy treatments (Fig. 3). The weedy treatments had a much patchier or sporadic distribution in comparison to the grass or perennial groundcover treatment in our experiment. This improvement in water infiltration from groundcovers in comparison to resident weed vegetation offers a reason to use groundcovers rather than just allowing weeds to grow in the vine rows.

The following groundcovers used in our study reduced 'Seyval blanc' shoot growth beyond desirable limits for wine grape production: english pennyroyal, companion grass, strawberry clover, and no weed control. The creeping thyme and veronica treatments were not competitive with the grapevines, but grew at rates far too slow to be considered practical
Aljibury, F.K. and L.P. Christensen. 1972. Water penetration of vineyard soils as modified by cultural practices. Amer. J. Enol. Viticult. 23(1):35-38.

Bordelon, B.P. and S.C. Weller, 1997. Preplant cover crops affect weed and vine growth in first-year

Boselli, M., C. Di Vaio, and B. Pica. 1998. Effect of soil moisture and transpiration on mineral content in leaves and berries of Cabernet Sauvignon grapevine. J. Plant Nutr. 21(6):1163-1178.

Cahoon, G. 1980. Fertilizing fruit crops. Ohio State Univ. Coop. Ext. Serv. Bul. 458.

Clement C.R. and J. DeFrank. 1998. The use of of-palm plantations in Hawaii. HortScience 33(5):814-815.

Edson, C.E., G.S. Howell, and J.A. Flore. 1995. Influence of crop load on photosynthesis and dry matter partitioning of Seyval grapevines. II. Seasonal changes in single leaf and whole vine photosynthesis. Amer. J. Enol. Viticult. 46(4):469-477.

Folorunso, O.A., D.E. Rolston, T. Prichard, and D.T. Louie 1992. Cover crops lower soil surface strength, may improve soil permeability. Calif. Agr. 46(6):26-27.

Gulick, S.H., D.W. Grimes, D.S. Munk, and D.A. Goldhamer, 1994. Cover-crop enhanced water vinyards. HortScience 32(6):1040-1043. groundcovers during the establishment of heart- 
infiltration of a slowly permeable fine sandy loam. Soil Sci. Soc. Amer. J. 58:1539-1546.

Hanninen, K. 2002. Tree-cover crop interactions: birch growth, competition and soil properties. $\mathrm{PhD}$ diss. Univ. Oulu, Hawaii.

Hejl, A.M., F.A. Einhellig, and J.A. Rasmussen. 1993. Effects of juglone on growth, photosynthesis, and respiration. J. Chem. Ecol. 19(3):559-568.

Hoffman, M.L., L.A. Weston, J.C. Snyder, and E.E. Regnier. 1995. Allelopathic influence of germinating seeds and seedlings of cover crops on weed species. Weed Sci. 44(3):579-584.

Ker, K. 2003. Weeds in young vines-How many is too many? Wine East 30(5):12-14.

Klik, A., J. Rosner, and W. Loiskandal. 1998. Effects of temporary and permanent soil cover on grape yield and soil chemical and physical properties. J. Soil Water Conserv. 53:249-253.

Kohli, R.K., D. Batish, and H.P. Singh. 1998. Allelopathy and its implications in agroecosystems. J. Crop Prod. 1(1):169-202.

Locke, M.A. and C.T. Bryson. 1997. Herbicidesoil interactions in reduced tillage and plant residue management systems. Weed Sci. 45(2):307-320.
Putnam, A.R., J. Defrank, and J.P. Barnes, 1983. Exploitation of allelopathy for weed control in annual and perennial cropping systems. J. Chem. Ecol. 9(8):1001-1010.

Reynolds, A.G. and A.P. Naylor. 1994. Pinot noir and Riesling grapevines respond to water stress duration and soil water-holding capacity. HortScience 29(12):1505-1510.

Rivera, T. 2002.Competitive performance in an apple berry polyculture. $\mathrm{PhD}$ diss. Ohio State Univ.

Skinner, P.W., J.A. Cook, and M.A. Matthews. 1988. Responses of grapevine cvs.Chenin blanc and Chardonnay to phosphorous fertilizer applications under phosphorous-limiting conditions. Vitis 27:95-109.

Skroch, W.A. and J.M. Shribbs, 1986. Orchard floor management: An overview. HortScience 21(3):390-392.

Smart, R.E. and B.G. Coombe. 1983. Water relations of grapevines Vitis, p. 137-196. In: Water deficits and plant growth. Academic Press, New York.

Smith. M.W., M.E. Wolf., B.S. Cheary, and B.L. Carroll. 2001. Allelopathy of bermudagrass, tall fescue, redroot pigweed, and cutleaf evening primrose on pecan. HortScience 36(6):1047-1048.
Smithyman, R.P., G.S. Howell, and D.P. Miller. 1997. Influence of canopy configuration on vegetative development, yield, and fruit composition of Seyval blanc grapevines. Amer. J. Enol. Viticult. 48(4):482-491.

Teasdale, J.R., C.E. Beste, and W.E. Potts. 1990. Response of weeds to tillage and cover crop residue. Weed Scie. 39:195-199.

Teasdale, J.R. and C.S.T. Daughtry. 1993. Weed suppression by live and desiccated hairy vetch (Vicia villosa). Weed Sci. 41:207-212.

Teasdale, J.R. and C.L. Mohler. 1993. Light transmittance, soil temperature, and soil moisture under residue of hairy vetch and rye. Agron. J. 85:673-680.

Toole, E.H., S.B. Hendricks, H.A. Borthwick, and V. Toole. 1956. The physiology of seed germination. Annu. Rev. Plant Physiol. 7:299-324.

Watson, M.E. and R.A. Isaac. 1990. Analytical instruments for soil and plant analysis, p. 691-740 In: R.L. Westerman (ed.). Soil testing and plant analysis. Soil Sci. Soc. Amer. Madison, Wis.

Winkler,A.J., J.A.Cook, W.M.Kliewer, and L.A.Lider. 1962. General viticulture. Univ. Calif. Press. 